\title{
Compositional Changes in Trans-Pecos Texas Magmatism Coincident with Cenozoic Stress Realignment
}

\author{
Eric W. James and Christopher D. HenRY
}

Bureau of Economic Geology, University of Texas at Austin

\begin{abstract}
The composition and inferred sources of Cenozoic magmas in Trans-Pecos Texas changed abruptly between 32 and $28 \mathrm{Ma}$, coincident with a fundamental change in stress regime. Magmas emplaced between 48 and 32 Ma comprise extended differentiation suites beginning with relatively evolved basaltic magmas. These rocks have low $\mathrm{Nb}$ and $\mathrm{Ta}$ compared to $\mathrm{Zr}, \mathrm{Hf}, \mathrm{La}, \mathrm{Ba}$, and $\mathrm{K}$, characteristics typical of continental volcanic arcs. However, the Texas rocks are more alkalic, have higher concentrations of incompatible elements, and have higher ratios of $\mathrm{Nb}$ and $\mathrm{Ta}$ to $\mathrm{Zr}, \mathrm{Hf}, \mathrm{La}$, $\mathrm{Ba}$, and $\mathrm{K}$ than is typical of rocks from arcs near trenches. These differences reflect relative position within the Cordilleran arc. Trace element models involving partial melting in the mantle wedge combined with fractional crystallization and assimilation of upper and lower crust can account for most of the observed trace element concentrations and ratios. Trans-Pecos magmatism may have involved smaller degrees of partial melting than is typical of arcs located closer to the subduction zone. Magmas emplaced after $31 \mathrm{Ma}$ were either bimodal, alkali basalt-rhyolite, or exclusively basaltic. They have high absolute abundances of incompatible trace elements and high ratios of $\mathrm{Nb}$ and $\mathrm{Ta}$ to $\mathrm{Zr}, \mathrm{Hf}$, $\mathrm{La}, \mathrm{Ba}$, and $\mathrm{K}$. The mafic rocks are typical of continental rift or ocean island basaits. Trace element models using $\mathrm{Nb}$, $\mathrm{Ta}, \mathrm{Y}, \mathrm{Yb}, \mathrm{Hf}$, and $\mathrm{Zr}$ reproduce the range of concentrations and ratios observed in these rocks and require very small degrees of partial melting, variable amounts of fractional crystallization, but little or no assimilation. The change in magma compositions and sources is best illustrated by a drop in $\mathrm{Zr} / \mathrm{Nb}$, from between 18 and 6.25 in the earlier, are rocks to between 6.25 and 2 in the later, rift-related rocks. Stress regime appears to play an important role in the process of magma generation and evolution. The change in trace element compositions indicative of tectonic setting supports interpretations of paleostress data that activity up to 31 Ma occurred in a continental volcanic arc, whereas later activity occurred in a setting of intraplate extension. The magmatic change may have been simultaneous with the change in stress regime or may have lagged by as much as $3-4$ m.y.
\end{abstract}

\section{INTRODUCTION}

Cenozoic volcanic and intrusive rocks in Trans-Pecos Texas represent the easternmost advance of Cenozoic magmatism in the United States and reflect conditions related to their position at the inboard fringe of the Cordilleran magmatic arc. They show the combined effects of location, age, and tectonics on magmatic composition. The Trans-Pecos igneous province extends (Figure 1) from the junction of the borders of New Mexico, Texas, and Chihuahua, Mexico, near the cities of Juarez and El Paso, $500 \mathrm{~km}$ southeast through the Big Bend region of Texas and into the state of Coahuila, Mexico. Rock compositions become more alkalic from southwest to northeast across the $150-\mathrm{km}$ width of the province. This zonation parallels compositional trends in the rest of the Cenozoic Cordilleran magmatic belt. Emplacement ages range from $48 \mathrm{Ma}$, closely postdating the end of Laramide folding, to $17 \mathrm{Ma}$, concurrent with Basin and Range faulting. This time interval spans the transition from a convergent to a transcurrent continental margin and a coincident change in regional stress regime at about $31 \mathrm{Ma}$ [Henry et al., this issue].

The tectonic setting of the Trans-Pecos igneous province has been a matter of interest since Lipman et al. [1972] first proposed that Cenozoic igneous rocks as far east as Colorado, New Mexico, and Texas were the consequence of subduction along the western margin of the North American plate. The Trans-Pecos rocks, however, are unusually alkaline compared to most arc rocks, and Barker [1977] suggested that their set-

\section{Copyright 1991 by the American Geophysical Union.}

Paper number $91 \mathrm{JB} 00203$.

0148-0227/91/91JB-00203\$05.00 ting was analogous to that of the Kenya rift. Further work [McDowell and Clabaugh, 1979; Barker, 1979; Damon et al., 1981; Cameron and Cameron, 1986; Cameron et al., 1986, 1989] illustrated the progression in ages and compositions in rocks stretching from the west coast of Mexico across the Sierra Madre Occidental and into Trans-Pecos Texas. This progression suggests that rocks in Trans-Pecos Texas with ages from $48 \mathrm{Ma}$ to at least as young as $31 \mathrm{Ma}$ are part of a single, long-lived magmatic arc.

In contrast, the youngest igneous rocks in Trans-Pecos Texas, 24-17 Ma alkali basalts, are contemporaneous with Basin and Range faulting. These basalts clearly postdate subduction at this latitude [Atwater, 1970] and are part of widespread Basin and Range magmatism across western North America. Although the origins of Basin and Range magmas are controversial, it is generally accepted that the basalts have asthenospheric sources and magmatic histories substantially different from those of the earlier magmas. This contrast between arc and Basin and Range magmas poses the question of the exact time of the transition. Many papers and arguments have addressed the timing of Basin and Range faulting and magmatism in areas throughout the Cordillera. Price and Henry [1984, 1988], Henry and Price [1986] and Henry et al. [this issue] present evidence for a major change in stress regime in Trans-Pecos Texas at about $31 \mathrm{Ma}$. Dike, vein, fault, and slickenline orientations indicate that the maximum principle stress $\left(\sigma_{1}\right)$ was east-northeast and the minimum principle stress $\left(\sigma_{7}\right)$ was north-northwest from $48 \mathrm{Ma}$ to $31 \mathrm{Ma}$. Henry et al. [this issue] interpret a change to $\sigma_{1}$ vertical and $\sigma_{3}$ east-northeast at $31 \mathrm{Ma}$ to mark the beginning of Basin and Range extension. Price et al. [1987] demonstrated differences in major element chemistry between Trans-Pecos Texas alkaline rocks emplaced during the earlier arc-related and those related to later extensional tectonic regimes. Cameron et al. [1986] and Gunderson et al. 

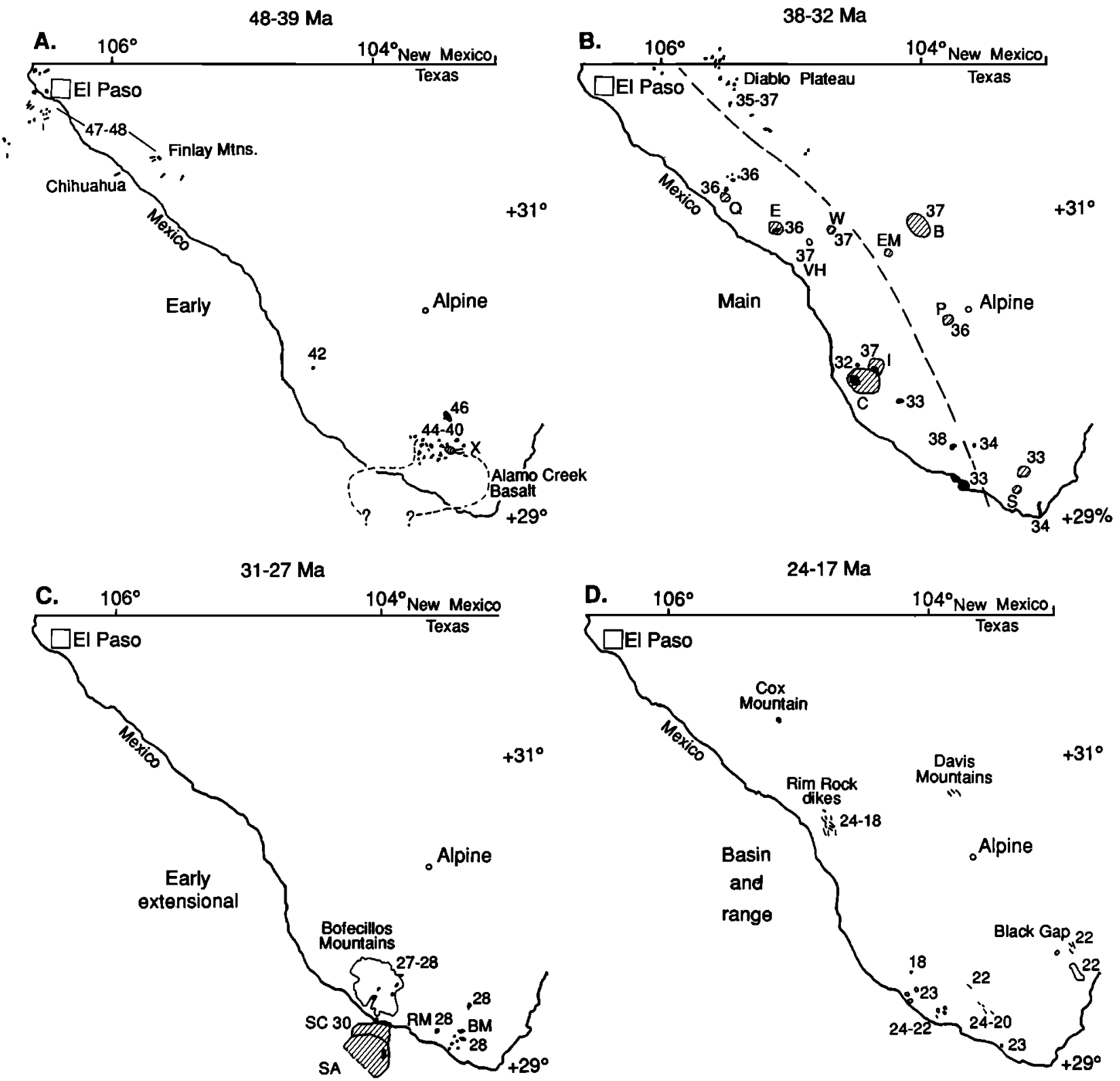

Fig. 1. Distribution of magmatism through time in Trans-Pecos Texas. Numbers indicate times of major activity of individual centers or areas of magmatism. Ruled areas are calderas and solid areas are major intrusions. (a) Early main phase, 48-39 Ma. Cross, Christmas Mountains caldera complex. (b) Main phase, 38-31 Ma. AC and A indicate alkali-calcic and alkalic belts. Q Quitman Mountains caldera; E, Eagle Mountains caldera; VH, Van Hom Mountains caldera; W, Wylie Mountains caldera; B, Buckhom caldera; EM, El Muerto caldera; P. Paisano volcano; I, Infiemito caldera; C, Chinati Mountains caldera; PC, Pine Canyon caldera; S, Sierra Quemada caldera. (c) early extensional phase, 31-27 Ma. SC, San Carlos caldera; Sa, Santana caldera; RM, Rattlesnake Mountain sill; BM, Burro Mesa. (d) Basin and Range phase, 24-17 Ma.

[1986] first noted that changes in trace element concentrations of rocks in the Big Bend area and adjacent Chihuahua, Mexico, were also coincident with the change in tectonic regime at about $31 \mathrm{Ma}$. This paper presents new major and trace element analyses for rocks in Trans-Pecos Texas, which more than double the number of trace element analyses for rocks emplaced in the extensional regime. These new data, along with published analyses from the entire geographic and age range of the TransPecos province, indicate a significant change in magma sources and evolution coincident with or slightly lagging the change in stress regime.

Igneous activity in Trans-Pecos Texas is divided into four age periods [Henry and McDowell, 1986]; 48-39 Ma, 38-31 Ma,
31-27 Ma, and 24-17 Ma (Figure 1). The first two phases, early and main phase arc-related magmatism, are clearly related but are distinguished by a significant increase in volume of magmatic activity at $38 \mathrm{Ma}$. The early extensional phase began at about $31 \mathrm{Ma}$, closely following main phase activity. As we show below, magmas emplaced between 31 and $27 \mathrm{Ma}$ have significaritly different sources and evolution than earlier rocks. The youngest phase comprises mafic lavas and dikes clearly related to Basin and Range faults. The next section describes each of the four phases in more detail.

Initial activity centered in two areas, one in the northem part of the province, stretching from El Paso and Juarez to the Finley Mountains, and a southern center in the Big Bend region 
(Figure 1a). Activity in the northem area comprises hypabyssal trachyandesite intrusions [Hoover et al., 1988]. The rocks are quartz normative and contain amphibole phenocrysts. Amphibole phenocrysts are absent in almost all rocks of the same age to the southeast and in all younger rocks. $\mathrm{K}$-Ar ages on several of these intrusions are 47 and $48 \mathrm{Ma}$, and field relations show that they postdate Laramide folds and faults.

Early magmatism in the Big Bend area is recorded by the 47-42 Ma Alamo Creek and Ash Spring basalts of the Chisos Formation and related small intrusions [Maxwell et al., 1967; Stewart, 1984; Schucker, 1986; Lonsdale, 1940; Gunderson et al., 1986]. Numerous sills, laccoliths, and stocks with ages between 47 and $40 \mathrm{Ma}$ extend northward into the Christmas Mountains where a small caldera complex has been mapped [Henry and Price, 1989]. Rock compositions range from basaltic to rhyolitic and include both nepheline and quartz normative series.

Main phase volcanism began at about $38 \mathrm{Ma}$ and continued through $32 \mathrm{Ma}$ across the entire province (Figure 1b). This period is typified by large-volume ash flow tuffs erupted from small to moderately large calderas and widespread intrusions and lava flows. These rocks represent the largest volume of volcanic material in Trans-Pecos Texas. Magmatism during this phase shows a clear zonation with respect to alkalinity [Barker, 1977]. An eastern, alkalic belt is defined by Peacock indices and the presence of clinopyroxene without orthopyroxene. Contemporaneous igneous centers in the western belt are alkali-calcic and have two pyroxenes. Cameron and Cameron [1986] consider the westem belt to be broadly calcalkalic based on mineralogy and geochemistry. Peralkaline rhyolite occurs in both belts, but nepheline-normative and nepheline-bearing rocks are found almost exclusively in the eastern alkalic belt.

Throughout main phase activity both alkalic and alkali-calcic magma sequences comprise extended differentiation suites that start with basaltic but relatively evolved magmas. Mafic endmembers are scarce and generally have low $\mathrm{Mg}$ numbers and $\mathrm{Ni}$ contents ( $<50 \mathrm{ppm})$, indicating that they are not primary compositions. Derivation of the evolved members is primarily by crystal fractionation, combined with variable amounts of assimilation of wall rock [Cameron et al., 1986; Nelson et al., 1987; Parker, 1983; Henry et al., 1988; Price et al., 1986].

Between 31 and $27 \mathrm{Ma}$ volcanic and intrusive rocks are found only in the southem part of the province (Figure 1c). The San Carlos and the Santana calderas, large but shallow, nested calderas just south of the Rio Grande formed at 30 and $28 \mathrm{Ma}$. Igneous rocks of these calderas are exclusively silicic, including ferroaugite rhyolites and granite [Gunderson et al., 1986]. Significant volumes of mafic to intermediate lavas were erupted nearby, north of the Rio Grande in the Bofecillos mountains at 28-27 Ma [McKnight, 1970; Urbanczyk, 1987]. Numerous alkaline and peralkaline laccoliths, dikes, and sills, typified by the Rattlesnake Mountain sill [Carman et al., 1975; Cameron et al., 1986], were emplaced in the Bofecillos Mountains and Big Bend area. Again, rocks are both nepheline and quartz normative with perhaps a slight shift toward greater volumes of undersaturated compositions. Taken together, rocks of this early extensional phase appear to be closer to a bimodal rhyolite-alkali basalt suite than main phase volcanic rocks.

The most recent phase of volcanic activity (24-17 Ma) includes only very small volumes of alkalic basalt to hawaiite (Figure 1d). Dikes and flows occur on Cox Mountain, in the Davis Mountains, Sierra Vieja (Rim Rock dikes), Bofecillos
Mountains, Big Bend area, and near Black Gap. Dikes are commonly related to Basin and Range faulting [Henry and Price, 1986; Henry et al., this issue]. These lavas have $\mathrm{Mg}$ numbers in the sixties, $\mathrm{Ni}$ contents greater than $100 \mathrm{ppm}$, and some dikes contain mantle xenoliths. These mafic rocks are the most primitive in Trans-Pecos Texas.

\section{Major and Trace Element Data}

New major and trace element analyses of low-silica rocks from the Trans-Pecos magmatic province are presented in Table 1. Additionally, this paper uses representative analyses compiled from the sources listed below to illustrate the changes in magmatic compositions with time. We have used analyses for which we have good geochronologic control from Barker [1977, 1987], Barker et al. [1977], Cameron and Cameron [1986], Cameron et al. [1986], Gunderson et al. [1986], Henry and Price [1986], Hoover et al. [1988], Irving and Frey [1984], Mathews and Adams [1986], Nelson and Nelson [1986], Nelson et al. [1987], Price et al. [1986, 1987], and Setter and Adams [1986]. Where we have new trace element data for previously analyzed samples, the newer, more accurate instrumental neutron activation analysis (INAA) data supplant older $X$ ray fluorescence (XRF) numbers.

To decrease chemical variations introduced by protracted fractionation and possible attendant assimilation and mixing, we have selected only the most $\mathrm{SiO}_{2}$-poor and $\mathrm{MgO}$-rich samples available from each area. Unfortunately, the scarcity of mafic compositions in some areas requires the inclusion of a few samples with as much as $57 \% \mathrm{SiO}_{2}$. All the volcanic rocks used in this study can be confidently placed in one of the age categories outlined in the introduction using volcanic stratigraphy, field relations, and abundant $\mathrm{K} / \mathrm{Ar}$ data [Henry et al., 1986].

The chemical data we have gathered come from several laboratories and were generated at different times using different techniques. Investigators who used INAA typically determined concentrations of $\mathrm{Ta}, \mathrm{Hf}$, and rare earth elements (REE) but not $\mathrm{Nb}, \mathrm{Zr}$, or $\mathrm{Y}$. Workers using XRF have determined $\mathrm{Nb}, \mathrm{Zr}$, and $Y$ but lack Ta, Hf, and heavy rare earth element (HREE) data. To allow comparison between suites analyzed for different trace elements, $\mathrm{Ta}, \mathrm{Hf}$, and $\mathrm{Yb}$ have been scaled to $\mathrm{Nb}, \mathrm{Zr}$, and $\mathrm{Y}$. Niobium, $\mathrm{Zr}, \mathrm{Ta}$, and $\mathrm{Hf}$ are all high field strength elements (HFSE) that are usually highly incompatible in mafic magmas. The similar ionic size and charge of $\mathrm{Nb}$ compared to $\mathrm{Ta}$ and of $\mathrm{Zr}$ compared to $\mathrm{Hf}$ mean that their geochemical behavior is similar regardless of tectonic regime. This allows scaling of Ta and $\mathrm{Hf}$ to $\mathrm{Nb}$ and $\mathrm{Zr}$ using typical basalt abundances. We have used concentrations of Ta times 16 and Hf times 39 [Gill, 1981] to substitute for missing $\mathrm{Nb}$ and $\mathrm{Zr}$ concentration data. Rocks for which we have $\mathrm{Y}$ and $\mathrm{Yb}$ concentration data average $\mathrm{Y} / \mathrm{Yb}$ of about 12.5. Therefore, we substitute $\mathrm{Yb}$ multiplied by 12.5 for rocks without $Y$ concentration data. These scaling factors are approximations, but we believe they are appropriate for reconnaissance studies. The similarities between scaled and unscaled data are apparent in Figure 3. In any case, scaling using chrondritic or mid-ocean ridge basalt (MORB) abundances for $\mathrm{Ta}, \mathrm{Hf}$, or $\mathrm{Yb}$ yields similar results. In the rest of this report we will refer to the combined data sets of unscaled and scaled concentrations with asterisks, i.e., $\mathrm{Zr}^{*}$ for the combined $\mathrm{Zr}$ and scaled $\mathrm{Hf}$ data set; $\mathrm{Nb}^{*}$ for $\mathrm{Nb}$ and $\mathrm{Ta}$; and $\mathrm{Y}^{*}$ for $\mathrm{Y}$ and $\mathrm{Yb}$. 


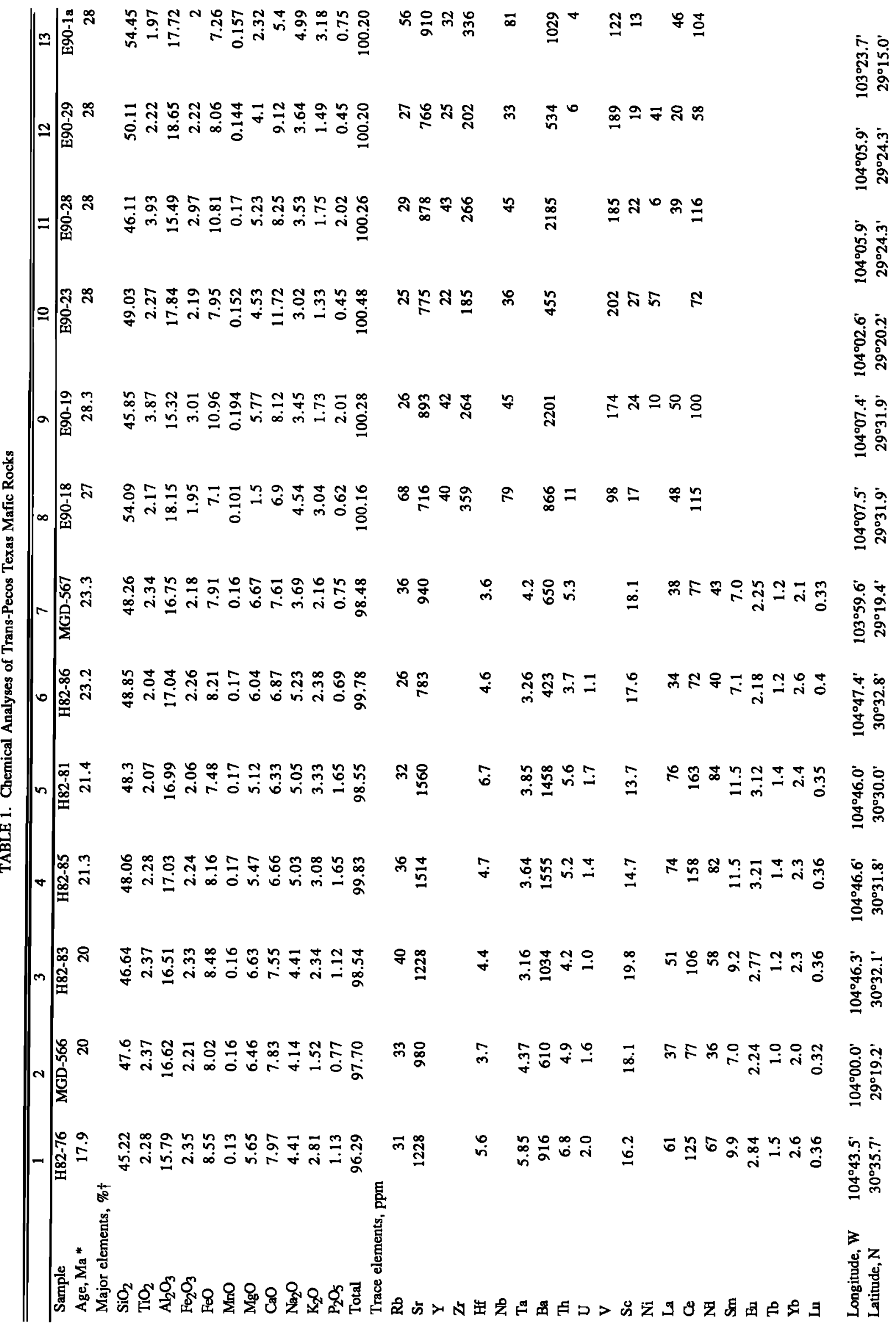




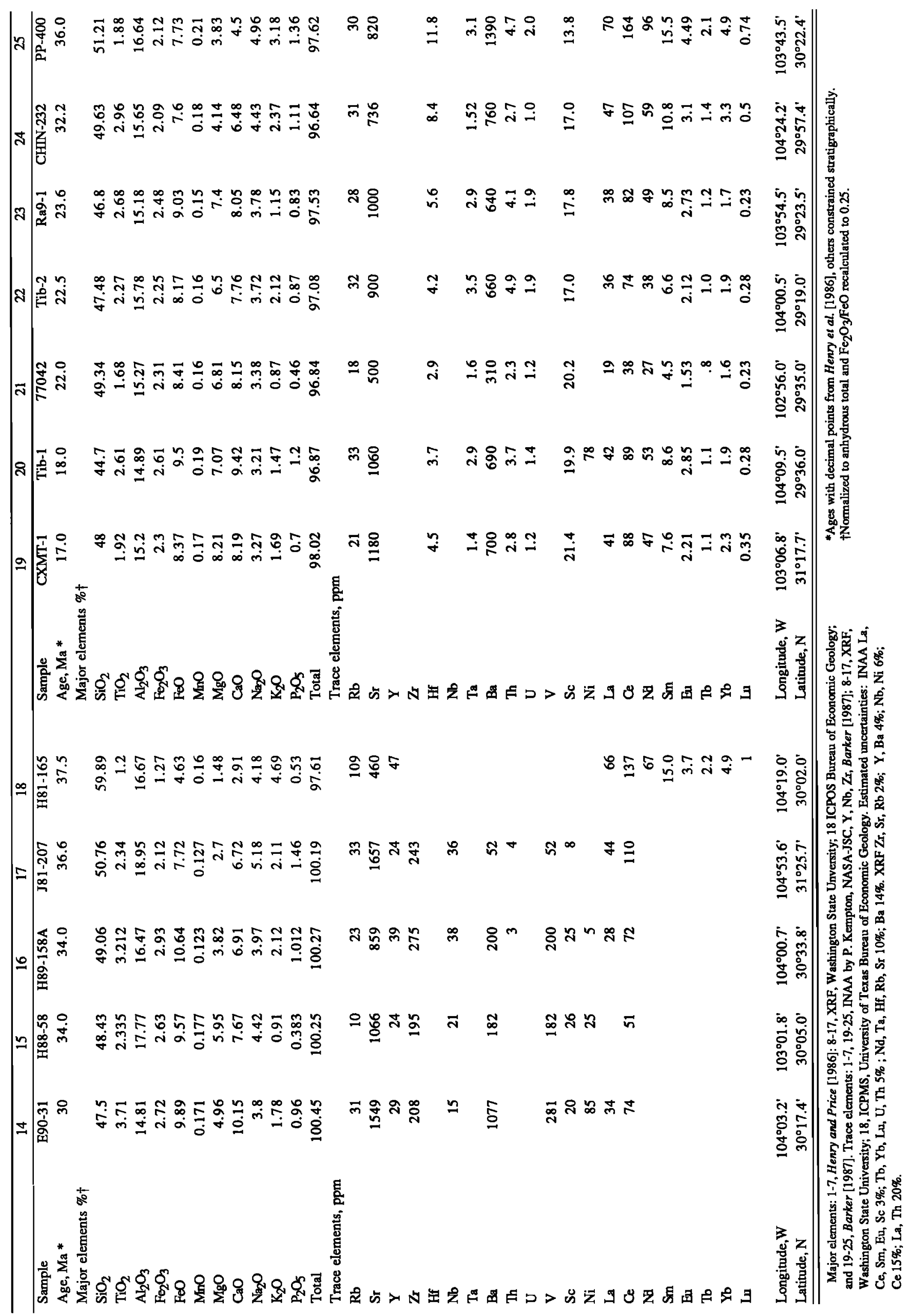


Geochemical. Evolution of Trans-Pecos Magmatism

\section{Major Elements}

The influence of tectonic regime on the major element compositions of Trans-Pecos province rocks has been briefly outlined in the introduction and more fully treated by Price et al. [1987]. Early and main phase (48-32 Ma) volcanic rocks have the evolved compositions and compositional ranges typically seen in arcs, although more alkaline than arcs closer to the subduction zone [Hildreth and Moorbath, 1988; Bacon, 1990]. The early extensional phase (31-27 Ma) rocks appear bimodal, and the basaltic volcanism (24-17 Ma) associated with Basin and Range faulting is exclusively basaltic. The percentage of mafic material increases with time, although the total volume of magma decreases from the main phase to the early extensional to the Basin and Range basalts. The question of arc versus continental extensional setting and the sources of the magmas can be addressed only partly in terms of the major element compositions and magmatic style. The early and main phases are clearly arc-related and the Basin and Range dikes and lava flows are extension-related basalts with asthenospheric sources. The setting and sources of the early extensional phase rocks are less obvious. However, the trace element contents of rocks from all phases provide a clearer indication of parentage.

\section{Trace Elements}

This study uses the consistent correlation between relative concentrations of certain trace elements and tectonic setting to document a change in magma sources and evolution coincident with a major stress reorientation. Many workers have documented differences between the concentrations of $\mathrm{Nb}, \mathrm{Ta}$, larger ion lithophile elements (LILE), Y, and REE commonly seen in arc versus intraplate mafic rocks [Gill, 1981; Pearce and Norry, 1979; Wood et al., 1979; Pearce, 1983]. Commonly cited indications of arc setting include low $\mathrm{Nb}, \mathrm{Ta}, \mathrm{Zr}, \mathrm{Ti}$, and Hf versus high $\mathrm{Cs}, \mathrm{Ba}, \mathrm{Rb}, \mathrm{K}, \mathrm{Th}, \mathrm{La}$, and $\mathrm{Ce}$. High $\mathrm{Nb}, \mathrm{Ta}$, $\mathrm{Zr}, \mathrm{Ti}$, and $\mathrm{Nb} / \mathrm{Zr}$ versus low $H R E E$ and $\mathrm{Y}$ are considered typical of intraplate or ocean island basalts. The petrologic mechanisms proposed for these contrasts between arc basalts and intraplate basalts range from generally well accepted to highly controversial. Current explanations include (1) residual garnet in the source region of intraplate basalts to retain HREE and $Y,(2)$ a subducted slab component greatly enriched in LREE, $\mathrm{Ba}$, and $\mathrm{K}$ which can give the appearance of a relative depletion of Ta and $\mathrm{Nb}$ [Kay, 1980; Pearce, 1983; Davidson and Wolff, 1989], (3) reaction of ascending arc melts with depleted peridotitic materials at the base of the crust [Meen and Ayres, 1989; Kelemen, 1990], (4) the presence of a $\mathrm{Ta}, \mathrm{Nb}$, and $\mathrm{Ti}$ retaining phase in the source region of arc magmas [Saunders et al., 1980], and (5) contamination of ascending magma in continental settings [Thompson et al., 1983; Hildreth and Moorbath, 1988]. These mechanisms are not mutually exclusive, and the actual source of trace element enrichments and depletions is certainly complex.

The typical trace element concentrations and ratios for arc and intraplate basalts can be illustrated on a element normalization diagram ("spidergram" of Thompson et al. [1984]) (Figure 2). As presented on this diagram arc basalts have lows at $\mathrm{Ta}$ and $\mathrm{Nb}$ and, to a lesser degree, at Ti. Arc basalts also have high concentrations of the LILE, $B a, R b, K$, and LREE. Basalts thought to have substantial asthenospheric sources, ocean island or intraplate basalts, have highs at Ta

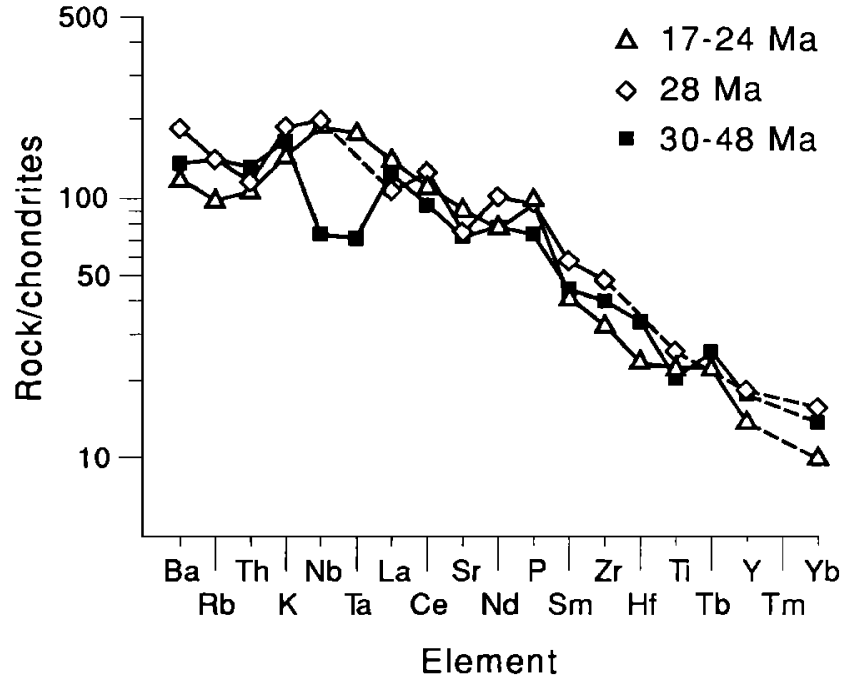

Fig. 2. Element nomalization diagram for averaged compositions of mafic igneous rocks from the main (48-31 Ma), early extensional (28-27 Ma), and Basin and Range (24-17 Ma) phases of Trans-Pecos Texas. Dashed lines indicate missing values. Data from sources listed in text. Normalization factors from Thompson et al. [1984].

and $\mathrm{Nb}$, also with relatively high LILE, moderate to high LREE, and low HREE and Y. Typical intraplate patterns are smooth and convex upward.

Most Trans-Pecos rocks emplaced between 48 and $31 \mathrm{Ma}$ have "arc-like" traces on normalization diagrams (Figure 2); they have an obvious, but shallow, dip at $\mathrm{Nb}$ or $\mathrm{Ta}$. In contrast, $28 \mathrm{Ma}$ rocks from Big Bend and the Bofecillos Mountains and 24-17 Ma Basin and Range basalts have broad highs at $\mathrm{Nb}$ and Ta (Figure 2). The trace elements from the three age groups of Trans Pecos rocks form a series representing changes in source and magmatic evolution with time. None of the rocks analyzed has the very low relative concentrations of $\mathrm{Ta}$ and $\mathrm{Nb}$ typical of the volcanic front of arcs adjacent to subduction zones.

Although element normalization diagrams allow comparisons between samples based on many trace elements at one time, it is difficult to compare elements that are not adjacent on the diagram. The visual trend of the data, together with normalization and log scaling, can obscure information. Individual trace element ratios avoid these shortcomings. We consider ratios commonly used to distinguish arc from intraplate magmatism: $\mathrm{Zr}^{*} / \mathrm{Nb}^{*}, \mathrm{Y}^{*} / \mathrm{Nb}^{*}$, and $\mathrm{Ba} / \mathrm{Nb}^{*}$. We first show the change of these ratios with time and stress regime and then present generalized models of magmatic processes that may account for their variation.

Change in trace element ratios at $31 \mathrm{Ma}$. Substantial changes in $\mathrm{Z}^{*} / \mathrm{Nb}^{*}, \mathrm{Y}^{*} / \mathrm{Nb}^{*}$, and $\mathrm{Ba} / \mathrm{Nb}^{*}$ (Figures 3 and 4 ) at about $31 \mathrm{Ma}$ amplify the differences evident in element normalization diagrams and substantiate the change in magma types correlative with change in stress regime [Price et al. 1987; Henry et al., this issue]. Trans-Pecos igneous rocks have several trace element characteristics that are indicative of differing magmatic processes. The youngest rocks, Basin and Range basalts, have high $\mathrm{Nb}^{*}$ compared with the other incompatible trace elements $\mathrm{Zr}^{*}, \mathrm{Y}^{*}$, and Ba (Figure 3). This is particularly clear in $\mathrm{Nb}^{*}$ versus $\mathrm{Zr}^{*}$. With one exception, $\mathrm{Zr}^{*} / \mathrm{Nb}^{*}$ falls below 5 in post-24 Ma rocks. Rocks with ages around $28 \mathrm{Ma}$, which include rocks from the Bofecillos Mountains, the Rattlesnake Mountain sill, and a mugearite intercalated with the Burro Mesa Rhyolite (Figure 1C) have intermediate ratios, 

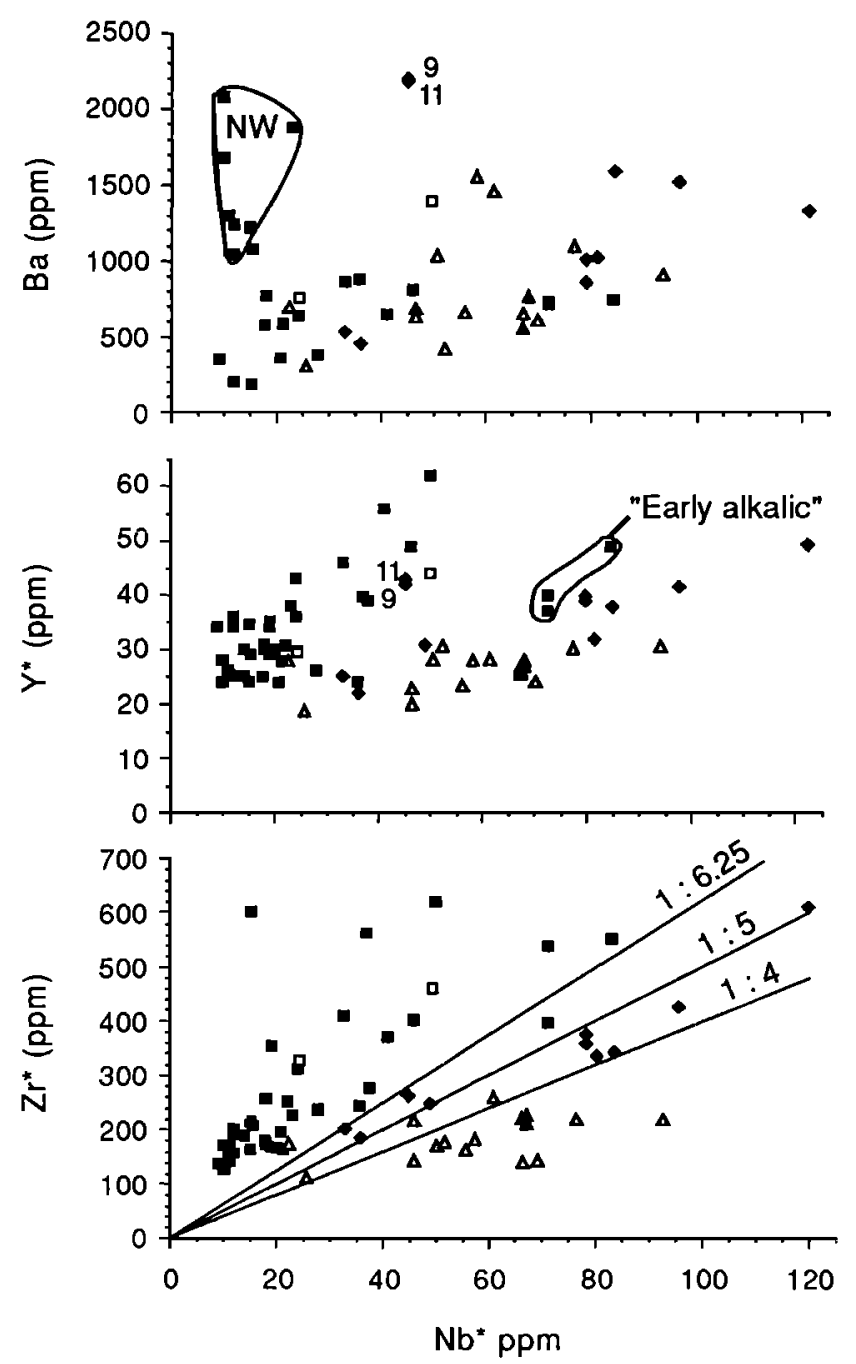

Fig. 3. Variation of $\mathrm{Zr}^{*}, \mathrm{Y}^{*}$, and $\mathrm{Ba}$ versus $\mathrm{Nb}^{*}$ in Trans-Pecos igneous rocks. Squares, 48-31 Ma samples; diamonds, 28-27 Ma samples; triangles, 24-17 Ma samples. Solid symbols: $\mathrm{Nb}, \mathrm{Z}$, and $\mathrm{Y}$; open symbols represent normalized dats, Ta X 16, Hf X 39, and Yb X 12.5 (see text). Lines on $\mathrm{Nb}^{*}$ versus $\mathrm{Zr}^{*}$ diagram show ratios of $\mathrm{Nb}^{*}$ to $\mathrm{Zr}^{*}$. Labeled fields and numbered data points are samples referred to in the text.

between 6.25 and 4. Rocks emplaced prior to $31 \mathrm{Ma}$, with one exception, have ratios greater than 6.25 .

Similar distinctions between pre- and post-31 Ma rocks are evident in $\mathrm{Nb}^{*}$ versus $\mathrm{Y}^{*}$ (Figure 3). Exceptions include some 47-42 Ma rocks from the Big Bend area and adjacent Chihuahua, which have $\mathrm{Nb}^{*}$ and $\mathrm{Y}^{*}$ concentrations similar to those of the post-31 Ma rocks. These exceptions have been described as an "early alkalic" phase of magmatism by Gunderson et al. [1986]. The two $28 \mathrm{Ma}$ rocks with relatively high $\mathrm{Y}^{*} / \mathrm{Nb}^{*}$ (Table 1 , analyses 9 and 11 ; Figure 3) are from one stratigraphic interval in the Bofecillos Mountains. These two aphyric basalt samples have unusually high $\mathrm{Y}$ and $\mathrm{Ba}$ contents, which may reflect crustal contamination.

The age groups show considerably less coherence and broad overlap in $\mathrm{Ba}$ versus $\mathrm{Nb}^{*}$ (Figure 3 ). Nevertheless, most rocks less than $31 \mathrm{Ma}$ have lower $\mathrm{Ba}$ at a given $\mathrm{Nb}^{*}$ content. The early alkalic group defined by relatively low $\mathrm{Y}^{*} / \mathrm{Nb}^{*}$ (Figure 3) has low $\mathrm{Ba} / \mathrm{Nb}^{*}$ as well. Samples 9 and 11 (Table 1), with high $\mathrm{Y}^{*} / \mathrm{Nb}^{*}$, also have exceptionally high Ba. The circled samples labeled NW on Figure 3 are 48-47 Ma trachyandesites from the northwestern end of the Trans-Pecos province [Hoover et al., 1988]. The origin of Ba enrichment in these samples is unknown but may reflect their evolved compositions and the presence of abundant amphibole phenocrysts.

All three sets of trace element ratios change between 31 and $28 \mathrm{Ma}$. This change is best illustrated by $\mathrm{Zr} * \mathrm{Nb}^{*}$ (Figure 4). This ratio decreases abruptly between 31 and $28 \mathrm{Ma}$ (Figure 4). Pre-31 Ma rocks have high $\mathrm{Zr}^{*} / \mathrm{Nb}^{*}$ typical of arc rocks. Early extensional ( $28 \mathrm{Ma}$ ) rocks have lower ratios; ratios in 24-17 Ma rocks, emplaced after the initiation of basin and range faulting, range to still lower values. The ratios from rocks younger than $31 \mathrm{Ma}$ are comparable to an average of 97 Basin and Range basalts from the southern U.S. Cordillera [Omerod et al., 1988].

A different measure of arc versus intraplate components with time is shown in Figure 5. This figure shows the change with time of concentrations of $\mathrm{Ta}$ or $\mathrm{Nb}$ normalized to chondrites, divided by the sum of normalized $\mathrm{K}$ and La divided by two. Ta and $\mathrm{Nb}$ fall between $\mathrm{K}$ and $\mathrm{La}$ on an element normalization diagram [Thompson et al. 1983]. Samples with values greater than 1 on Figure 5 have peaks on normalization diagrams at $\mathrm{Nb}$ or Ta. Samples with values less than 1 have lows. The increase after $31 \mathrm{Ma}$ indicates a switch from magmas with high LILE and LREE and low HFSE typical of arcs to magmas with high HFSE associated with intraplate sources and processes.

The time of change in trace element signature is constrained to be between 32 and $28 \mathrm{Ma}$, while the stress change is constrained to have occurred near $31 \mathrm{Ma}$. Analyzed rocks at 28 and $32 \mathrm{Ma}$ are well dated [Henry et al., 1986] and bracket the change in stress regime and magma sources. Few mafic rocks were emplaced in Trans-Pecos between these times; the one data point at $30 \mathrm{Ma}$ (Figures 4 and 5 and Table 1, analysis 14) is stratigraphically constrained only between 32 and $28 \mathrm{Ma}$. Therefore, we currently cannot resolve the precise contemporaniety of changes in magma sources and stress regime in Trans-Pecos Texas.

Processes affecting trace element signatures. Despite the slight temporal uncertainty, clearly there is a change in trace element chemistry of Trans-Pecos mafic rocks broadly coincident with the change in stress regime at $31 \mathrm{Ma}$. This observation poses several interesting questions. Is the contemporaniety coincidental? What mechanisms account for the evolution of different trace element signatures? How could stress regime and these evolutionary mechanisms be linked? We suggest that processes of partial melting, fractional crystallization and assimilation generated the trace element variation and are linked to stress regime. The contemporaniety of change is not coincidental.

The three sets of trace element ratios presented in Figure 3 suggest some possible sources and evolutionary influences on Trans-Pecos rocks. In the most primitive rocks these ratios can help suggest possible mantle source compositions. $\mathrm{Zr}^{*} / \mathrm{Nb}^{*}$ is sensitive to the degree of partial melting and proportion of clinopyroxene and garnet [Kempton et al., 1987], while $\mathrm{Y}^{*} / \mathrm{Nb}^{*}$ is more sensitive to gamet in the source. $\mathrm{Ba} / \mathrm{Nb}^{*}$ indicates LILE-enriched components attributed to dehydration of the subducting slab [Kay, 1980] and also may indicate assimilation of crust. However, the behavior of $\mathrm{Ba}$ in continental arc settings is complicated, and high $\mathrm{Ba} / \mathrm{Nb}$ may not be specific to either slab or crustal sources [Hildreth and Moorbath, 1988]. All three sets of ratios in Figure 3 are sensitive to fractional crystallization and assimilation of crust. The basis for these generalized correlations of trace element ratios with specific sources and 


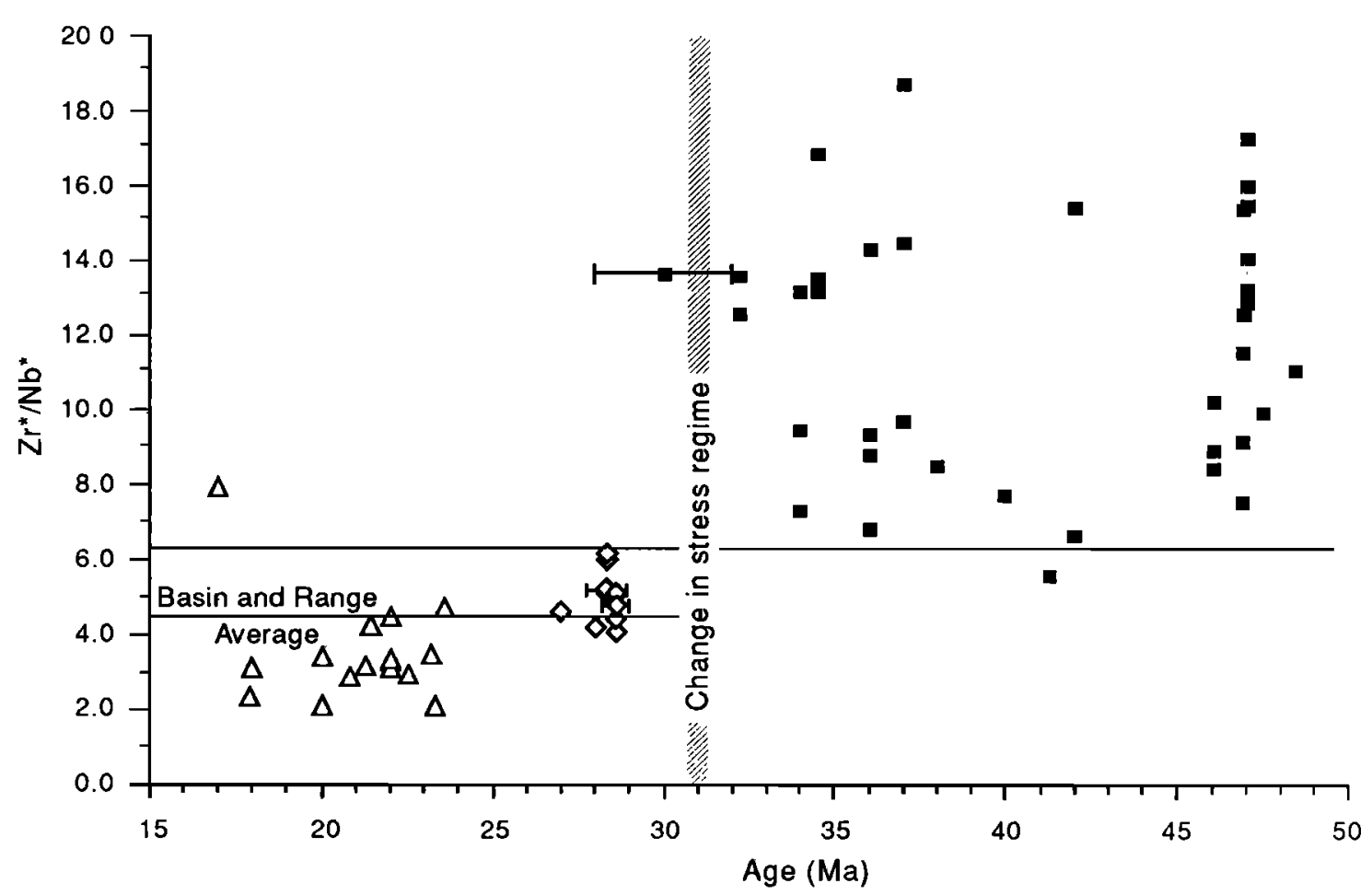

Fig. 4. Variation of $\mathrm{Zr}^{*} / \mathrm{Nb}^{*}$ with age in Trans-Pecos mafic rocks. Triangles are Basin and Range alkali basalts; diamonds, early extensional basalts to mugearites; squares, main phase basalts to trachyandesites. Line indicating Basin and Range average is from data of Omerod et al. [1988]. Bars on samples near $28 \mathrm{Ma}$ are uncertainties from Henry et al. [1986] and are typical for most points. Bars on 30 Ma sample represent uncertainties in age based on stratigraphic constraints. Age of stress regime transition from Price and Henry [1984] and Henry et al. [this issue].

processes can be illustrated by modeling trace element behavior. These models also suggest several links between stress regime and the products of magmatic evolution.

Three types of processes are important in the evolution of Trans-Pecos igneous rocks: partial melting in the source region, fractional crystallization, and assimilation or mixing of crustal materials. Our aim is to model some of the possible evolutionary paths reflecting these processes and compare these paths to the analyses we have compiled. These models are intended only to indicate possible trends or influences on magmatic evolution in Trans-Pecos rocks, not as examples of what did happen.

Partial melting: The partial melting model used is modal batch melting:

$$
C_{1}=C_{0}\{D+F(1-P)]
$$

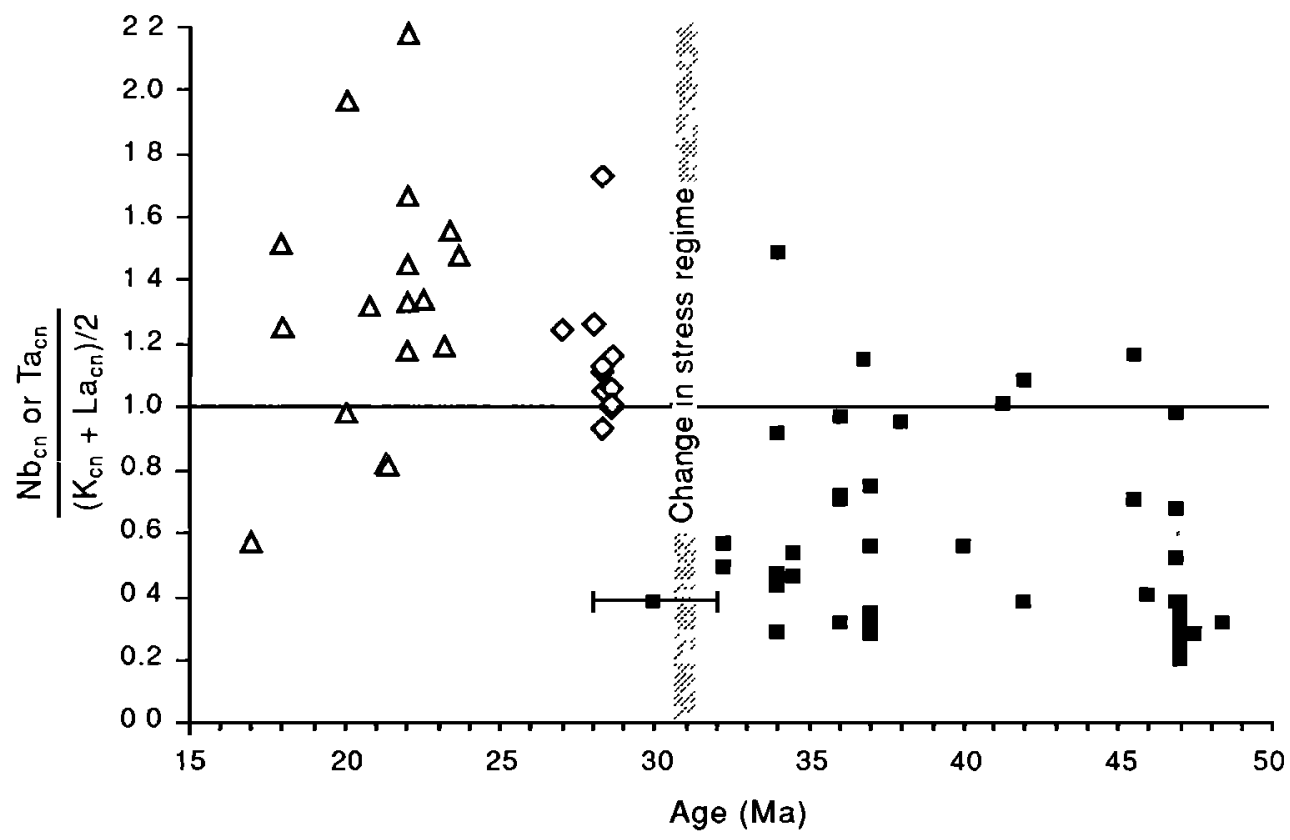

Fig. 5. Nb or $\mathrm{Ta}$, normalized to chondrites, divided by normalized $\mathrm{K}$ plus $\mathrm{La}$, divided by 2 versus age. Values greater than 1 have $\mathrm{Nb}$ or Ta "highs" on a element normalization diagram; values less than 1 have lows. Symbols as in Figure 3. 
TABLE 2. Data for Partial Melting and AFC Models

\begin{tabular}{|c|c|c|c|c|c|c|c|}
\hline & \multicolumn{4}{|c|}{ Distribution Coefficents* } & \multirow{2}{*}{$\begin{array}{l}\text { Lherzolite } \\
\text { Mode }\end{array}$} & \multirow{2}{*}{$\begin{array}{c}\text { Melting } \\
\text { Proportions }\end{array}$} & \multirow{2}{*}{$\begin{array}{c}\text { Fractionating } \\
\text { Assemblage }\end{array}$} \\
\hline & $\mathbf{N b}$ & $\mathbf{Z r}$ & $\mathbf{Y}$ & Ba & & & \\
\hline Olivine & 0.005 & 0.01 & .001 & 0.0001 & 0.58 & 0.09 & 0.4 \\
\hline Clinopyroxene & 0.01 & 0.27 & 0.36 & 0.001 & 0.15 & 0.2 & 0.3 \\
\hline Orthopyroxene & 0.015 & 0.03 & 0.01 & 0.001 & 0.22 & 0.7 & \\
\hline Spinel & 0.4 & 0.1 & 0.2 & 0.001 & 0.05 & 0.01 & 0.03 \\
\hline Gamet & 0.1 & 0.3 & 2.0 & 0.08 & or 0.05 & 0.01 & \\
\hline Plagioclase & 0.01 & 0.01 & 0.03 & 0.15 & & & 0.25 \\
\hline Apatite & 0.001 & 0.001 & 10.0 & 0.001 & & & 0.02 \\
\hline Spinel lherzolite bulk $D$ & 0.028 & 0.058 & 0.067 & 0.0005 & & & \\
\hline Gamet lherzolite bulk $D$ & 0.013 & .068 & 0.157 & 0.004 & & & \\
\hline Fractionating bulk $D$ & 0.0195 & .091 & 0.322 & 0.038 & & & \\
\hline \multicolumn{8}{|c|}{ Compositions, ppm } \\
\hline Lherzolite source $\dagger$ & 1.1 & 8 & 3.1 & 12 & & & \\
\hline Lower crust assimilant $\S$ & 35 & 431 & 59 & 968 & & & \\
\hline Upper crust assimalant $\$$ & 12 & 175 & 34 & 652 & & & \\
\hline
\end{tabular}

- Partition coefficients are from tabulation of Kempton et al. [1987], Kuehner et al. [1989], and Pearce and Norry [1979].

$\dagger$ Lherzolite starting material is an average of enriched lherzolite [O'Reilly and Griffin, 1988; Hartmain and Wedepohl, 1990] and depleted lherzolite [O'Reilly and Griffin, 1988; Salters and Shimizu, 1988].

8 Lower crust composition is "ADC" from Cameron et al. [1989]. Upper crust is an average of Precambrian thyolites from the Carizo Mountains Group [Rudnick, 1983].

where $C_{1}$ is the concentration of the trace element in the melt, $C_{0}$ the concentration in the melting rock, $D$ the bulk distribution coefficient with the mineral components weighted by mode in the melting rock, $F$ the fraction melted, and $P$ the bulk distribution coefficient with the mineral components weighted by the proportion of the mineral entering the melt. Two source mineralogies, a garnet therzolite and a spinel lherzolite, with the same chemical composition are used to represent different depths of melting. Distribution coefficients, modal and melting proportions, and trace element contents used in the model are listed in Table 2. These variables are necessarily compromises; they ignore the temperature, pressure, and compositional dependence of partition coefficients and assume simple initial composition, fractionating assemblages, and contaminants.

Figure 6 compares trace element concentrations and ratios calculated for partial melting, fractional crystallization and assimilation to the observed concentrations. A ratio can be visualized as the slope of a line from the origin through a point. In these models, ratios of concentrations are probably more accurate than the calculated concentrations due to uncertainties and variations in distribution coefficients. These variations would be expected to cancel, in part, when expressed as ratios.

Curves labeled gt and sp on Figure 6 show the trace element concentrations calculated for between 0.1 and $20 \%$ partial melting of garnet and spinel therzolite. The proportion of gamet or spinel is $5 \%$. This is high compared to most lherzolite xenoliths and tends to accentuate calculated differences in trace element ratios. This is particularly true of $\mathrm{Y}^{*}$ concentrations, which are heavily dependent on the percentage of gamet. Low degrees of partial melting of garnet lherzolite produce melts with low $\mathrm{Zr}^{*} \mathbf{N b}^{*}$ and $\mathbf{Y}^{*} / \mathrm{Nb}^{*}$ (Figure 6) similar to those of the post-31 Ma rocks. With progressively larger degrees of partial melting the curve trends toward the composition of the melting lherzolite, marked by a circle near the origin (Figure 6). The spinel lherzolite melting curves lie above the garnet-bearing compositions with higher concentrations of $\mathrm{Zr}^{*}$, $\mathrm{Y}^{*}$, and $\mathrm{Ba}$ and higher ratios with respect to $\mathrm{Nb}$. Partial melts of more than $3 \%$ of either starting lithology have similar $\mathrm{Nb}^{*}$, $\mathrm{Zr}^{*}$, and $\mathrm{Ba}$ concentrations, but $\mathrm{Y}^{*}$ remains distinctly higher at over $10 \%$ melting of spinel lherzolite.

This model suggests that small degrees of partial melting of garnet therzolite can yield melts with trace element ratios and concentrations approaching those of the post-31 Ma mafic rocks of Trans-Pecos Texas. Model partial melting of spinel lherzolite produces $\mathrm{Y}^{*} / \mathrm{Nb}^{*}$ ratios that are too high to match most of the post-31 Ma rocks, but similar to those measured in mafic pre-31 Ma rocks. Higher degrees of partial melting of either garnet or spinel lherzolite yield $\mathrm{Zr}^{*} / \mathrm{Nb}^{*}$ and $\mathrm{Ba} / \mathrm{Nb}^{*}$ ratios closer to, but not equalling, most of those of the older, pre-31 Ma suite. The concentrations calculated for $15-20 \%$ partial melting are much lower than those measured in any of the pre-31 Ma rocks. Given that most of the pre-31 Ma TransPecos rocks are not primitive, it is not surprising that partial melting alone is insufficient to model their trace element ratios and concentrations.

Fractional crystallization: Rayleigh crystallization of magma compositions derived by $3 \%$ partial melting of gamet lherzolite are modeled for comparison with the compositions of post-31 Ma rocks (Figure 6). The heavy curves on these figures show 0-50\% fractionation of a low-pressure assemblage consisting of olivine, clinopyroxene, spinel, plagioclase, and apatite (40:30:3:25:2). Fractionation of a moderate pressure assemblage, typical of type II lherzolite xenoliths, of clinopyroxene, spinel, and olivine (85:10:5) yields nearly identical curves. Although the model crystallization trajectories follow the trend of concentrations and maintain the trace element ratios measured in post-31 Ma rocks, they do not generate the 

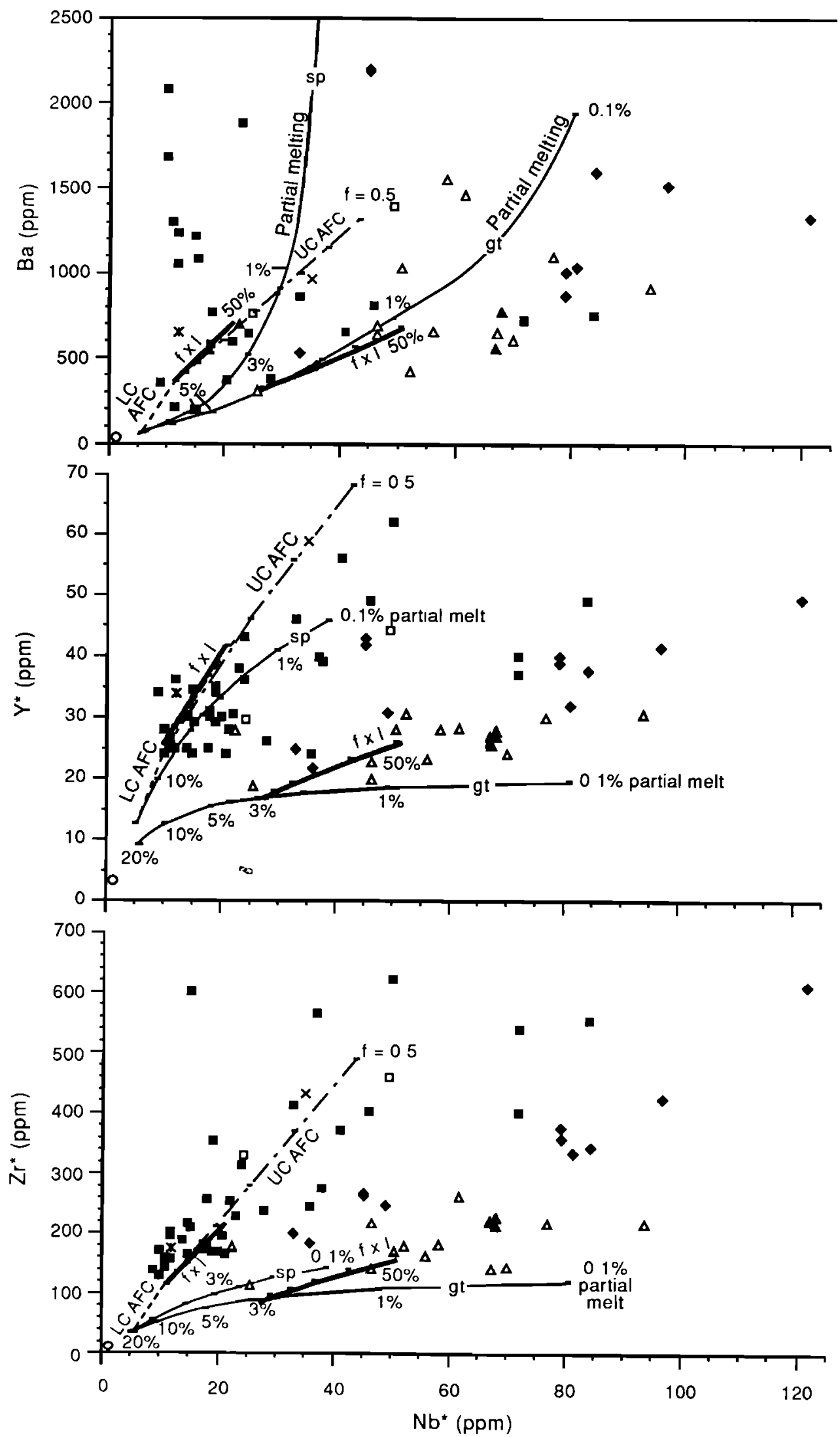

Fig. 6. Trace element concentrations calculated from partial melting, fractional crystallization, and assimilation-fractional crystallization models compared to observed concentrations (symbols as in Figure 5). Constants and compositions of starting materials and assimilants are presented in Table 2. Thin lines labeled $\mathrm{gt}$ and sp show calculated concentrations for batch partial melting of gamet and spinel lherzolite compositions shown by circles near the origin. Ticks show percentage melting. Bold lines labeled fxl show effect of 0-50\% Rayleigh fractionation on 3\% partial melt of gamet therzolite and on the products of lower crustal AFC. Dashed lines labeled LC AFC show calculated effect of lower crustal AFC using $f$ (fraction crystallized) $=0.05, r$ (ratio of rate of assimilation to rate of crystallization) $=0.9$ and lower crust assimilant marked by asterisk. Dash-dotted curves labeled UC AFC show effect of modeled upper crustal AFC on the product of lower crustal AFC. The upper crust assimilant is shown by cross, $f=0$ to $0.5, r=0.4$. Ticks indicate 0.1 changes in $f$. 
high trace element concentrations observed. The high concentrations would require either large amounts of fractionation or starting melts generated by very small degrees of partial melting.

Our models show up to $50 \%$ crystallization, which seems a reasonable upper limit considering that all the measured compositions have less than $57 \% \mathrm{SiO}_{2}$ and the great majority have less than $52 \% \mathrm{SiO}_{2}$ However, experiments on natural alkali basalts [Mahood and Baker, 1986] show that moderately primitive basalts with $46 \% \mathrm{SiO}_{2}$ may fractionate as much as $70 \%$ and still yield basaltic compositions with $50 \% \mathrm{SiO}_{2}$. This larger percentage of crystallization would improve the fit of our models to the observed concentrations.

Model melting calculations commonly yield concentrations that are lower than those observed in rocks [Frey et al., 1978; Fitton and Dunlop, 1985; Kempton et al., 1987]. Our simple models ignore or only approximate several processes that might yield higher concentrations. A more primitive or metasomatized mantle source than the average of enriched and depleted lherzolite comprising the model source would certainly yield higher concentrations. Model concentrations could be increased by calling on zone refining, magma mixing, or fractionation of an assemblage with lower bulk distribution coefficients. Additionally, reaction of small partial melts with large volumes of mantle may increase concentrations of incompatible elements [Fitton and Dunlop, 1985]. Nonetheless, the models fit the data reasonably given the chemical and mineralogical assumptions.

The partial melting model suggests larger degrees of melting to duplicate the evolutionary trends of the pre 31-Ma arc rocks. Calculated trace element ratios for $20 \%$ partial melting of either spinel or gamet lherzolite approach the measured ratios in the pre-31 $\mathrm{Ma}$ rocks; however, the calculated concentrations are much lower than those observed. Fractional crystallization alone cannot increase the concentrations in the partial melts sufficiently without assuming an unrealistic amount of fractionation. Also, because the elements used in modeling are nearly equally incompatible, fractional crystallization of reasonable mineral assemblages does not appreciably change the starting ratios to bring them closer to the measured ratios. We suggest that models that involve assimilation of crust may account for higher $\mathrm{Y}^{*} / \mathrm{Nb}^{*}, \mathrm{Zr}^{*} / \mathrm{Nb}^{*}$, and $\mathrm{Ba} / \mathrm{Nb}^{*}$ in the pre-31 Ma rocks.

Assimilation-fractional crystallization: Fractional crystallization with assimilation in two different settings are modeled below using the equations of DePaolo [1981]. We assume a high ratio of assimilation to fractional crystallization $(r=0.9)$ and a small amount of crystallization, $f=0.05$, in the lower crust. The relatively high temperature of the deep wall rock is assumed to slow crystallization but facilitates assimilation. Bulk distribution coefficients are derived from the data in Table 2. The $\mathrm{Nb}, \mathrm{Zr}$, $\mathrm{Y}$, and $\mathrm{Ba}$ concentrations assumed for the lower crustal rock assimilated are those of average deep crust of Cameron et al. [1989]. These data were derived from studies of crustal xenoliths from near La Olivina, Chihuahua, Mexico, which lies about $200 \mathrm{~km}$ south of the Trans-Pecos province. The initial composition of the magma is modeled as a $20 \%$ melt of model spinel lherzolite, although garnet lherzolite would yield similar results.

The dashed lines extending up from the $20 \%$ tick on the partial melting curves on Figure 6 show the calculated effects of assimilation-fractional crystallization in the lower crust. Small amounts of fractional crystallization and assimilation of deep crust could bring the trace element ratios and concentrations of relatively large partial melts into the range of the least enriched pre-31 Ma mafic rocks.

The thick solid lines, continuing upward from the dashed lines modeling lower crustal AFC, show the calculated effects of $0-50 \%$ fractional crystallization alone on the composition derived by lower crustal AFC. The trace element ratios remain near the analyses of pre-31 Ma rocks but model concentrations are lower than most of the observed concentrations.

The addition of an upper crustal contaminant in concert with further fractional crystallization can provide a better match to the concentration data. The dash-dotted lines in Figure 6 show the calculated effect of AFC in the upper crust on the magma modified by AFC in the lower crust. The second stage of assimilation and fractional crystallization assumes an $r$ of 0.4 and a range of crystallization proportions $(f)$ from 0 to 0.5 . The composition of the upper crustal assimilant is represented by an average of rhyolites from the Precambrian Carrizo Mountain Group [Rudnick, 1983]. These rocks crop out in the northwestern part of the Trans-Pecos volcanic province near Van Horn, Texas. Lead isotopic data [James and Henry, 1990] suggest similar basement underlies much of Trans-Pecos Texas, at least as far southeast as the Davis and Bofecillos mountains.

Many of the analyses of pre-31 Ma rocks have $\mathrm{Nb}^{*}, \mathrm{Zr}^{*}$, and $\mathrm{Y}^{*}$ concentrations that might be explained by a single stage of AFC in the lower crust and fractional crystallization with little or no upper crustal contamination. Nevertheless, some rocks have concentrations above the highest modeled concentrations generated from combined upper and lower crustal assimilation and fractional crystallization, indicating processes outside our model. Furthermore, the fit between model $\mathrm{Nb}^{*}$ versus $\mathrm{Ba}$ and the observed concentrations is not as clear as $\mathrm{Nb}^{*} / \mathrm{Zr}^{*}$ or $\mathrm{Nb} \mathbf{b}^{*} / \mathrm{Y}^{*}$.

The models presented so far have not considered the effects of the different sources represented by the subducting slab versus the mantle. Obviously, the slab contributes substantially to the trace element budget of arc magmas [Kay, 1980; Gill, 1981]. The trace element signature of arcs, a high ratio of LILE to HFSE, can be ascribed to both the composition and effects of fluids evolved from the slab. These fluids promote partial melting in the overlying mantle wedge. As modeled above, with increasing partial melting the concentrations of HFSE, particularly $\mathrm{Nb}$, decrease. The slab fluids also contribute high concentrations of $L I L E$ elements, $K, \mathrm{Cs}, \mathrm{Rb}$, and $\mathrm{Ba}$. The various trends modeling $\mathrm{Nb}^{*}$ versus $\mathrm{Ba}$ (Figure 6) follow the data rather poorly and the lack of a LILE-enriched slab component in our model partially accounts for the poor fit. However, these data also show less correlation between age group and $\mathrm{Ba} / \mathrm{Nb}^{*}$. This suggests decoupling of the behavior of LILE and HFSE or multiple crustal and mantle sources. Notably, Hildreth and Moorbath [1988] also found complex behavior of $\mathrm{Ba}$ in Andean arc rocks. We find it difficult to attribute differences in $\mathrm{Ba}$ concentration in the Trans-Pecos province to a simple mechanism.

The effects of stress regime: All the components in the models presented above would be influenced by stress regime. Intuitively, the proportion of partial melting would be less in an extensional environment than in a compressional or neutral setting. Extensional environments should allow melting and melt migration at deeper, less depleted levels in the mantle. Melts would coalesce and migrate upward easily in an extensional regime, reacting relatively little with the uppermost, depleted mantle or the crust. In a compressional environment, ascending melts would rise more slowly, allowing more 


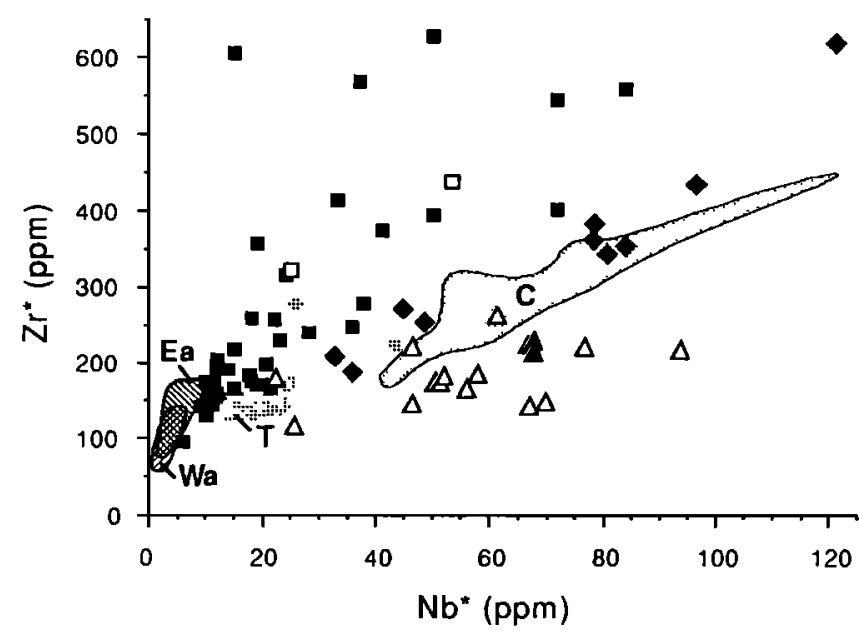

Fig. 7. Comparison of $\mathrm{Nb}^{*}$ and $\mathrm{Zr}^{*}$ in Trans-Pecos igneous rocks (symbols as in Figure 3) to $\mathrm{Nb}$ and $\mathrm{Zr}$ in rocks from the southem Andes and Patagonia. Shaded fields indicale westem part of the southem Andes [Hickey et al., 1986], Wa; eastem volcanic centers in the southem Andes [Hickey et al., 1989], Ea; "transitional," T, and "cratonic," C, Patagonian plateau lavas [Stern et al., 1990].

extensive fractional crystallization and therefore additional time and heat for assimilation. These processes would influence both the initial melt compositions and their subsequent evolution. Our simple models assume a single starting chemical composition, yet we are able to generate distinct trace element suites similar to those observed for rocks that evolved during different stress regimes in Trans-Pecos Texas. Separate depleted and enriched starting compositions, rather than an average, and addition of slab sources should provide an even better fit between model and observed concentrations and ratios.

\section{Comparison of Magmatism in Trans-Pecos Texas AND THE SOUTHERN ANDES}

Results of trace element modeling suggest that differences in Trans-Pecos rocks associated with a change in stress regime are related to differences in degree of partial melting, fractional crystallization, and assimilation. Similar processes and tectonic environments have been proposed for rocks of the southern Andean arc and Patagonian plateau [Hickey et al., 1986, 1989; Stern et al., 1990; Hildreth and Moorbath, 1988]. Comparison of $\mathrm{Zr}$ and $\mathrm{Nb}$ concentrations in the Andean suites with those of the Trans-Pecos igneous province shows some interesting parallels and differences. The western Andean arc rocks, those closest to the trench, have low $\mathrm{Zr}$, very low $\mathrm{Nb}$, and high $\mathrm{Zr} / \mathrm{Nb}$. Eastern Andean arc rocks, slightly farther from the trench, have slightly higher $\mathrm{Zr}$ and $\mathrm{Nb}$ concentrations. These concentrations overlap with the lower range of concentrations in 48-31 Ma Texas samples. However, $\mathrm{Zr}$ and $\mathrm{Nb}$ concentrations in Trans-Pecos rocks extend to much higher values. We suggest two possible reasons. The more alkaline compositions of the Trans-Pecos rocks imply that they represent smaller degrees of partial melting and consequently would have higher incompatible element abundances. Additionally, many of the Texas samples are more differentiated and perhaps more contaminated than the Andean samples, which have a maximum $\mathrm{SiO}_{2}$ content of $50.2 \%$. Differentiation of the enriched west Texas magmas would further increase incompatible element concentrations.
"Transitional" Patagonian plateau basalts (field T, Figure 7) in and east of the southern Andean arc have $\mathrm{Zr}$ and $\mathrm{Nb}$ compositions intermediate between the Andean arc lavas to the west and intraplate "cratonic" basalts (field C) to the east [Stern et al., 1990]. They are more Nb-rich than the arc rocks and have $\mathrm{Nb}$ and $\mathrm{Zr}$ contents at the lower end of the trends formed by $28 \mathrm{Ma}$ and post-24 Ma Trans-Pecos basalts and hawaiites. Rocks farther east, cratonic Patagonian plateau basalts, show similar concentrations to those of post-31 Ma rocks in Trans-Pecos Texas. These plateau basalts contain mantle xenoliths and have major and trace elements compositions that clearly reflect their intraplate sources.

There are further contrasts between Trans-Pecos Texas and the Andean/Patagonian suites. The variations in Andean/ Patagonian trace element abundances reflect geographic and probably tectonic variations. The Andean rocks formed in an arc environment close to a continental margin. The back arc setting and continental sedimentation [Stern et al., 1990] associated with the transitional and cratonic Patagonian lavas suggests an extensional environment east of the arc. TransPecos rocks show a parallel variation, but the change in tectonic setting is a function of age rather than location. Older TransPecos rocks (pre-31 Ma) were emplaced in an arc farther from the continental margin than the Andean rocks. The post-31 Ma rocks were emplaced in an extensional, perhaps back arc, setting.

The geographic distribution of magma types and sources in Andean/Patagonian suites has been attributed to decreasing degrees of partial melting in the mantle wedge from west to east, a concurrent decrease in LILE-enriched slab component, and an increasing contribution from convecting asthenospheric sources [Stern et al., 1990]. Further variability developed by assimilation as melts ascended through thick crust [Hildreth and Moorbath, 1988]. We believe similar sources and processes also affected the Trans-Pecos rocks.

\section{Discussion}

Changes in the major and trace element compositions of the Tertiary igneous rocks of Trans-Pecos Texas with time indicate major changes in sources and processes, in turn linked to a change in tectonic setting. These findings support and amplify interpretations of paleostress data [Henry et al., this issue] that show $\sigma_{1}$ was east-northeast and $\sigma_{3}$ was northnorthwest from 48-31 $\mathrm{Ma}$ and changed abruptly to $\sigma_{1}$ vertical and $\sigma_{3}$ was east-northeast at $31 \mathrm{Ma}$. Henry et al. infer a continental arc setting up to $31 \mathrm{Ma}$ and one of intraplate extension afterwards. Rocks emplaced during the 48-31 Ma period are differentiated alkali-calcic and alkalic rocks with lower $\mathrm{Nb}$ and $\mathrm{Ta}$ compared to $\mathrm{Zr}, \mathrm{Hf}, \mathrm{La}, \mathrm{Ba}$, and $\mathrm{K}$ than later rocks. These compositions are typical of the interior edge of continental magmatic arcs. Rocks emplaced after the change to an extensional regime at $31 \mathrm{Ma}$ are initially bimodal and then, after $24 \mathrm{Ma}$, exclusively basaltic. These rocks have higher $\mathrm{Nb}$ and Ta compared to $\mathrm{Zr}, \mathrm{Hf}, \mathrm{La}$, and $\mathrm{K}$. Compositions are characteristic of intraplate and ocean island basalts.

Although element normalization diagrams and the various trace element ratios used in this study clearly show a contrast between the pre- and post-31 Ma rocks, they also indicate that the pre-31 Ma rocks do not have the same mix of sources as arcs adjacent to a trench. The trace element abundances in arc rocks from Trans-Pecos Texas are higher, and relative concentrations lie between those of arcs adjacent to subduction 
zones and intraplate basalts. Furthermore, a few analyses of 48-31 Ma rocks have diagnostic trace element ratios that overlap with post-31 Ma rocks. On the basis of trace element abundances, Gunderson et al. [1986] suggested that these early alkalic rocks were only indirectly related to subduction. These rocks are, however, intimately associated with rocks that have an unequivocal subduction trace element component.

We suggest that all the pre-31 $\mathrm{Ma}$ rocks are indeed subduction-related but that they have compositions controlled by a distinct environment. The position of the Trans-Pecos magmatic province at the eastern edge of the Cordilleran arc implies generation of melts above the deeper parts of the subducting slab compared to more westem magmatism. We speculate that this deeper, distal process of melt generation would involve (1) a slab partially depleted of water and LILErich components, (i.e., the slab component), (2) relatively small degrees of partial melting for an arc, (3) possibly a greater fraction of $F$ in any remaining fluid liberated from the slab due to breakdown of F carrying phases, (4) a thick mantle wedge, and (5) a substantial thickness of continental crust. The first two factors, a fluid-depleted slab and small degrees of partial melting, would reduce the slab-derived fluid flux. In turn, this effect would reduce the contrast in concentrations between HFSE and LILE plus LREE typically seen in arc magmas while concurrently keeping alkalies high. Derivation of this melt from the mantle wedge and further interaction with it during ascent could also mute an arc trace element signature. High-fluorine activities could accentuate the ability of these melts to extract and carry HFSE from the wedge and continental crust.

The similarities in compositions of all the 48-31 Ma mafic rocks in Trans-Pecos Texas, both the westem alkali-calcic and eastem alkalic belts, corroborate the conclusion that they are part of the same magmatic arc [McDowell and Clabaugh, 1979; Barker, 1979]. Although the eastem belt includes some distinctive alkaline rocks, the minor differences between trace element compositions of mafic members of the two belts imply broadly similar sources and processes. This is particularly evident in the contrast between minor differences seen in the 48-31 Ma alkalic versus alkali-calcic suites and the larger differences between pre-31 $\mathrm{Ma}$ and post-31 Ma rocks.

Furthermore, the compositions of the 48-31 Ma Trans-Pecos rocks show that alkalic rocks, including nepheline-bearing and peralkaline suites, occur in arc settings. It is a common misconception that high alkalinity precludes an arc setting and indicates an extensional tectonic regime. Several recent studies provide additional examples of alkaline rocks in arc and nonextensional settings. Richards et al. [1990] document a suite of trace element-enriched alkalic basalts in Papua New Guinea that were emplaced during subduction. They cite numerous examples of intraplate basalts emplaced in arc settings coincident with changes in tectonic configuration [Richards et al., 1990, references therein]. A suite of alkaline intrusions in Scotland at the northwest edge of the coeval Caledonian calcalkalic magmatic belt [Halliday et al., 1987] provides a close parallel to the Trans-Pecos 48-31 Ma rocks. The alkaline intrusives in Scotland are subparallel to the Moine thrust and crosscutting relations indicate that movement on the thrust was concurrent with emplacement. These relations indicate that alkaline magmatism took place in a compressional arc environment [Halliday et al., 1987]. In fact, this environment is more compressional than the Trans-Pecos arc, where $\sigma_{3}$ was horizontal during main phase magmatism.
In contrast to the pre-31 Ma rocks, the 28-17 Ma suites are dominated by intraplate mantle sources with no obvious arcrelated components. Decreasing $\mathrm{Zr}^{*} / \mathrm{Nb}^{*}$ in the post-31 $\mathrm{Ma}$ suites (Figure 3) suggests that deeper or more fertile sources were tapped with time. This change is evident in the 24-17 Ma suite [Dasch et al., 1987]. The temporal change of trace element compositions from arc to intraplate magmatism in Trans-Pecos Texas is paralleled by the geographic change of compositions in southern Andean arc and Patagonian plateau lavas.

Although we have emphasized the temporal evolution of magmatic compositions within the Trans-Pecos magmatic province, there are larger regional variations we have not discussed. After $31 \mathrm{Ma}$, substantial magmatic activity to the west is arc related and has a clear arc trace element signature. This includes the southern cordilleran basaltic andesite suite of Cameron et al. [1989], which comprises extensive lavas with arc geochemistry erupted in a probable extensional tectonic environment. Consideration of these rocks shows that the variation in compositions in Trans-Pecos Texas is not simply temporal but is also part of a geographic arc-to-intraplate gradient. This perspective validates the analogy between the southern Andes/Patagonia and Trans-Pecos Texas-Chihuahua.

Acknowledgments. We thank Pamela Kempton and Julius Dasch of NASA, Houston, for INAA analyses. We are grateful for reviews of an early version of this manuscript by A. Laughlin, C. Chapin, D. Barker, K. Cameron, and A. Glamner. Research support was provided by the U.S. Bureau of Mines grant G1194148 to the Texas Mining and Mineral Resources Research Institute and by the COGEOMAP program of the U.S. Geological Survey (Cooperative Agreement 14-08-0001-A0408 and 14-08-0001-A0662).

\section{REFERENCES}

Atwater, T., Implications of plate tectonics for the Cenozoic tectonic evolution of western North America, Geol. Soc. Am. Bull., 81, 35133536, 1970.

Bacon, C. R., Calc-alkaline, shoshonitic, and primitive tholeiitic lavas from monogenetic volcanoes near Crater Lake, Oregon, J. Petrol., 31 , 135-166, 1990.

Barker, D. S., Northem Trans-Pecos magmatic province: Introduction and comparison with the Kenya rift, Geol. Soc. Am. Bull., 88 1421$1427,1977$.

Barker, D. S., Cenozoic magmatism in the Trans-Pecos Magmatic province: Relation to the Rio Grande Rift, in Rio Grande Rift: Tectonics and Magmatism, edited by R. E. Riecker, pp. 382-392, AGU, Washington, D.C., 1979.

Barker, D. S., Tertiary alkaline magmatism in Trans-Pecos Texas, in Alkaline Igneous Rocks, edited by J. G. Fitton and B. G. J. Upton, Geol. Soc. Spec. Publ. London, 30, 415-431, 1987.

Barker, D. S., L. E. Long, G. K. Hoops, and F. N. Hodges, Petrology and Rb-Sr isotope geochemistry of intrusions in the Diablo Plateau, northern Trans-Pecos magmatic province, Texas and New Mexico, Geol. Soc. Am. Bull., 88, 1437-1446, 1977.

Cameron, K. L., and M. Cameron, Geochemistry of quartz-normative igneous rocks from the Chinati Mountains and Terlingua areas, West Texas: A comparison with Cenozoic volcanic rocks from Chihuahua and Baja California Sur, Mexico, Guideb. 23, pp. 143163, Bur. of Econ. Geol., Univ. of Tex. at Austin, 1986.

Cameron, K. L., G. J. Nimz, D. Kuentz, and S. Gunn, Southern Cordilleran basaltic andesite suite, southern Chihuahua, Mexico: A link between Tertiary continental arc and flood basalt magmatism in North America, J. Geophys. Res., 94, 7817-7840, 1989.

Cameron, M., K. L. Cameron, and M. F. Carman, Jr., Alkaline rocks in the Terlingua-Big Bend area of Trans-Pecos Texas, Guideb. 23, pp. 123-142, Bur. of Econ. Geol., Univ. of Tex. at Austin, 1986.

Carman, M. F., Jr., M. Cameron, B. Gunn, K. L. Cameron, and J. C. Butler, Petrology of Rattlesnake Mountain sill, Big Bend National Park, Texas, Geol. Soc. Am. Bull., 86, 177-193, 1975.

Damon, P. E., M. Shafiqullah, and K. F. Clark, Age trends of igneous activity in relation to metallogenesis in the southem Cordillera, Ariz. Geol. Soc. Dig., 14, 137-154, 1981. 
Dasch, E. J., C. D. Henry, J. G. Price, P. G. Kempton, and L. W. Snee, Rim Rock dike swarm, Trans-Pecos Texas, Geol. Soc. Am. Abstr. Programs, 19, 150, 1987.

Davidson, J. P., and J. A. Wolff, On the origin of the Nb-Ta "anomaly" in arc magmas, $E S$, Trans. $A G U, 70,1387,1989$.

DePaolo, D. J., Trace element and isotopic effects of combined wallrock assimilation and fractional crystallization, Earth Plonet. Sci. Lett., 53, 189-202, 1981.

Fitton, J. G., and H. M. Dunlop, The Cameroon line, West Africa, and its bearing on the origin of oceanic and continental alkali basalt, Earth Planet. Sci. Lett., 72, 23-38, 1985.

Frey, F. A., D. H. Green, and S. D. Roy, Integrated models of basalt petrogenesis: a study of quartz tholeiites to olivine melilitites from southeastern Australia utilizing geochemical and experimental petrological data, J. Petrol., 19, 463-513, 1978.

Gill, J. B., Orogenic Andesites and Plate Tectonics, 390 pp., SpringerVerlag, New York, 1981.

Gunderson, R., K. L. Cameron, and M. Cameron, Mid-Cenozoic calcalkalic and alkalic volcanism in eastem Chihuahua, Mexico: Geology and geochemistry of the Benavides-Pozos area, Geol. Soc. Am. Bull., 97, 737-753, 1986

Halliday, A. N., M. Aftalion, I. Parsons, A. P. Dickin, and M. R. W. Johnson, Syn-crogenic alkaline magmatism and its relationship to the Moine Thrust Zone and the thermal state of the lithosphere in NW Scotland, J. Geol. Soc., London, 144, 611-617, 1987.

Hartmann, G., and K. H. Wedepohl, Metasomatically altered peridotite xenoliths from the Hessian Depression (northwest Germany) Geochim. Cosmochim. Acta, 54, 71-86, 1990.

Henry, C. D., and F. W. McDowell, Geochronology of the mid-Tertiary volcanic field, Trans-Pecos Texas, Guideb. 23, pp. 99-122, Bur. of Econ. Geol., Univ. of Tex. at Austin, 1986.

Henry, C. D., and J. G. Price, Early Basin and Range development in Trans-Pecos Texas and adjacent Chihuahua: Magmatism and orientation, timing, and style of extension, J. Geophys. Res., 91, 6213$6224,1986$.

Henry, C. D., and J. G. Price, The Christmas Mountains caldera complex, Trans-Pecos Texas: Geology and development of a laccocaldera, Bull. Volcanol., 52, 97-112, 1989.

Henry, C. D., F. W. McDowell, J. G. Price, and R. C. Smyth, Compilation of potassium-argon ages of Tertiary igneous rocks, Trans-Pecos Texas, Geol. Circ. 86-2, 34 pp., Bur. of Econ. Geol., Univ. of Tex. at Austin, 1986.

Henry, C. D., J. G. Price, and R. C. Smyth, Chemical and thermal zonation in a mildly alkaline magma system, Infiemito caldera, Trans-Pecos Texas, Contrib. Mineral. Petrol., 98, 194-211, 1988.

Henry, C. D., J. G. Price, and E. W. James, Mid-Cenozoic stress evolution and magmatism in the southem Cordillera, Texas and Mexico: Transition from a continental arc to intraplate extension. J. Geophys Res., this issue.

Hickey, R. L., F. A. Frey, D. C. Gerlach, and L. Lopez-Escobar, Multiple sources for besaltic arc rocks from the southern volcanic zone of the Andes $\left(34^{\circ}-41^{\circ} \mathrm{S}\right)$ : Trace element and isotopic evidence for contributions from subducted oceanic crust, mantle, and continental crust, J. Geophys. Res., 91, 5963-5983, 1986.

Hickey, R. L., H. Moreno, L. Lopez-Escobar, and F. A. Frey, Geochemical variations in Andean basaltic and silicic lavas from Villarica-Lanin volcanic chain $\left(39.5^{\circ} \mathrm{S}\right)$ : An evaluation of source heterogeneity, fractional crystallization and crustal assimilation, Contrib. Mineral. Petrol., I03, 361-386, 1989.

Hildreth, W., and S. Moorbath, Crustal contributions to arc magmatism in the Andes of Central Chile, Contrib. Mineral. Petrol., 98, 455-489, 1988.

Hoover, J. D., S. E. Ensenat, C. G. Bames, and R. Dyer, Early TransPecos magmatism: Petrology and geochemistry of Eocene intrusive rocks in the El Paso area, Field Conf. Guideb. N. M. Geol. Soc., 39, 109-118, 1988.

Irving, A. J., and F. A. Frey, Trace element abundances in megacrysts and their host basalts: Constraints on partition coefficients and megacryst development, Geochim. Cosmochim. Acta, 48, 1201-1221, 1984.

James, E. W., and C. D. Henry, Accreted late Paleozoic terrane in Trans-Pecos Texas: Isotopic mapping of the buried Ouachita front. Geol. Soc. Am. Abstr. Programs, 22, 329, 1990.

Kay, R. W., Volcanic arc magmas: Implications of a melting-mixing model for element recycling in the crust-upper mantle system, J. Geol., 88, 497-522, 1980
Keleman, P. B., Reaction between ultramafic rock and fractionating basaltic magma, I, Phase relations, the origin of calc-alkaline magma series, and the formation of discordant dunite, J. Petrol., 31, 51-98, 1990.

Kempton, P. D., M. A. Dungan, and D. P. Blanchard, Petrology and geochemistry of xenolith-bearing alkalic basalts from the Geronimo Volcanic field, southeast Arizona: Evidence for polybaric fractionation and implications for mantle heterogeneity, Spec. Pap. Geol. Soc. Am., 215, 347-370, 1987.

Kuehner, S. M., J. R. Laughlin, L. Grossman, M. L. Johnson, and D. S. Burnett, Determination of trace element mineral/liquid partition coefficients in melitite and diopside by ion and electron microprobe techniques, Geochim. Cosmochim. Acta, 53, 3115-3130, 1989.

Lipman, P. W., H. J. Prostka, and R. L. Christiansen, Cenozoic volcanism and plate-tectonic evolution of the Western United States1, Early and Middle Cenozoic, Philos. Trans. Soc. London, Ser. A, 271, 217-248, 1972

Lonsdale, J. T., Igneous rocks of the Terlingua-Solitario region, Texas, Geol. Soc. Am. Bull., 51, 1539-1626, 1940.

Mahood, G. A., and D. R. Baker, Experimental constraints on depths of fractionation of mildly alkalic basalts and associated felsic rocks: Pantelleria, Strait of Sicily, Contrib. Mineral. Petrol., 93, 251-264, 1986.

Matthews, W. K., II, and J. A. S. Adams, Geochemistry, age, and structure of the Sierra Blanca and Finlay Mountain intrusions, Hudspeth County, Texas, Guideb. 23, pp. 207-224, Bur. of Econ. Geol., Univ. of Tex. at Austin, 1986.

Maxwell, R. A., J. T. Lonsdale, R. T. Hazzard, and J. A. Wilson, Geology of Big Bend National Park, Brewster County, Texas, Publ. 6711,320 pp., Bur. of Econ. Geol., Univ. of Tex. at Austin, 1967.

McDowell, F. W., and S. E. Clabaugh, Ignimbrites of the Sierra Madre Occidental and their relations to the tectonic history of western Mexico, Spec. Pap. Geol. Soc. Am., 180, 113-124, 1979.

McKnight, J. F., Geology of Bofecillos Mountains area Trans-Pecos Texas, Geol. Quad. Map 37, scale 1:48,000, 36 pp., Bur. of Econ. Geol., Univ. of Tex. at Austin, 1970.

Meen, J. K., and J. C., Ayres, Cryptic metasomatism and creation of melts with depleted contents of the high-filed-strength elements: Coupled effects due to infiltration of melt into harzburgite, $B u l l . N$. M. Bur. of Mines Miner. Resour., 131, 185, 1989.

Nelson, D. O., K. L. Nelson, K. D. Reeves, and G. D. Mattison, Geochemistry of Tertiary alkaline rocks of the eastem Trans-Pecos magmatic province, Texas, Contrib. Mineral. Petrol., 97, 72-92, 1987.

Nelson, K. L., and D. O. Nelson, Magmatic evolution of the Van Hom Mountains caldera and comparison with alkaline magmatism in the eastern Trans-Pecos Magmatic belt, west Texas, Guideb. 23, pp. 164-177, Bur. of Econ. Geol., Univ. of Tex. at Austin, 1986.

O'Reilly, S. Y., and W. L. Griffin, Mantle metasomatism beneath westem Victoria, Australia: I. Metasomatic processes in Cr-diopside lherzolites, Geochim. Cosmochim. Acta, 52, 443-448, 1988.

Omerod, D. S., C. J. Hawksworth, N. W. Rogers, W. P. Leeman, and M. P. Menzies, Tectonic and magmatic transitions in the western Great Basin, USA, Nature, 333, 349-353, 1988.

Parker, D. F., Origin of the trachyte-quartz trachyte-peralkalic rhyolite suite of the Oligocene Paisano volcano, Trans-Pecos Texas, Geol. Soc. Am. Bull. 94, 614-629, 1983.

Pearce, J. A., Role of the sub-continental lithosphere in magma genesis at active continental margins, in Continental Basalts and Mantle Xenoliths, edited by C. Hawksworth and M. J. Norry, pp. 230-249, Shiva, Cambridge, Mass., 1983.

Pearce, J. A., and M. J. Norry, Petrogenetic implications of Ti, Zr, Y, and $\mathrm{Nb}$ variations in volcanic rocks, Contrib. Mineral. Petrol., 69, 33-47, 1979.

Price, J. G., and C. D. Henry, Stress orientations during Oligocene volcanism in Trans-Pecos Texas: Timing the transition from Laramide compression to Basin and Range extension, Geology, 12 , 238-241, 1984

Price, J. G., and C. D. Henry, Dikes in Big Bend National Park: Petrologic and tectonic significance, Cent. Field Guide S-Cent., pp. 435-440, Geol. Soc. of Am., Boulder, Colo., 1988.

Price, J. G., C. D. Henry, D. S. Barker, and J. N. Rubin, Petrology of the Marble Canyon stock, Culberson County, Texas, Guideb. 23, pp. 353-360, Bur. of Econ. Geol., Univ. of Tex. at Austin, 1986.

Price, J. G., C. D. Henry, D. S. Barker, and D. F. Parker, Alkalic rocks of contrasting tectonic settings in Trans-Pecos Texas, Spec. Pap. Geol. Soc. Am., 215, 335-346, 1987. 
Richards, J. P., B. W. Chappell, and M. T. McCulloch, Intraplate-type magmatism in a continent-island-arc collision zone: Porgera intrusive complex, Papua New Guinea, Geology, 18, 959-961, 1990.

Rudnick, R. L., Petrography, geochemistry and tectonic affinities of the meta-igneous rocks of the Carrizo Mountain Group, Van Horn, Texas: M.S. thesis, 100 pp., Sul Ross State Univ., Alpine, Tex., 1983.

Salters, V. J. M, and N. Shimizu, Word-wide occurrence of HFSEdepleted mantle, Geochim. Cosmochim. Acta, 52, 2177-2182, 1988.

Saunders, A. D., J. Tamey, and S. D. Weaver, Transverse variations across the Antarctic Peninsula: Implications for the genesis of calcalkaline magmas, Earth Planet. Sci. Lett., 46, 344-360, 1980.

Schucker, D. E., Geochemistry and petrogenesis of the mafic flow units within the Chisos Formation, Big Bend National Park, Texas, Master's thesis, 206 pp., Sul Ross State Univ., Alpine, Tex., 1986.

Setter, J. R. D., and J. A. S. Adams, Petrology and geochemistry of the Quitman Mountains, Hudspeth County, Texas, Guideb. 23, pp. 178-206, Bur. of Econ. Geol., Univ. of Tex. at Austin, 1986.

Stern, C. R., F. A. Frey, K. Futa, R. E. Zartman, Z. Peng, and T. K. Kyser, Trace element and $\mathrm{Sr}, \mathrm{Nd}, \mathrm{Pb}$, and $\mathrm{O}$ isotopic composition of Pliocene and Quatemary alkali basalts of the Patagonian Plateau lavas of southemmost South America, Contrib. Mineral. Petrol., 104, 294-308, 1990.

Stewart, R. M., Stratigraphy and petrology of the Alamo Creek Basalt Big Bend National Park, Texas, Master's thesis, 186 pp., Univ. of Houston, Houston, Tex., 1984.
Thompson, R. N., M. A. Morrison, A. P. Dickin, and G. L. Hendry, Continental flood basalts... arachnids rule OK?, in Continental Basalts and Mantle Xenoliths, edited by C. J. Hawkesworth and M. J. Norry, pp. 158-185, Shiva, Cambridge, Mass., 1983.

Thompson, R. N., M. A. Morrison, G. L. Hendry, and S. J. Parry, An assessment of the relative roles of a crust and mantle in magma genesis; An elemental approach, Philos. Trans. R. Soc. London, Ser. A, 310, 549-590, 1984.

Urbanczyk, K. M., Petrogenesis of the Rawls Formation, Bofecillos Mountains, Trans-Pecos Texas, Master's thesis, 156 pp., Sul Ross State Univ., Alpine, Tex, 1987.

Wood, D. A., J. L. Joron, and M. Treuil, A re-appraisal of the use of trace elements to classify and discriminate between magma series enupted in different tectonic settings, Earth Planet. Sci. Lett., 45, 326-336, 1979

C. D. Henry and E. W. James, Bureau of Economic Geology, University of Texas at Austin, Austin, TX 78713.

(Received July 2, 1990;

revised October 25, 1990;

accepted January 10, 1991.) 